\title{
THE EXPORT PERFORMANCE OF INDONESIA'S PALM OIL IN INTERNATIONAL MARKET
}

\author{
Maria Ulfah"), R. Hanung Ismono ${ }^{*}$, and Ktut Murniati*) \\ *) Study Program of Agribusiness, Faculty of Agriculture, University of Lampung \\ Jl. Prof. Dr. Soemantri Brojonegoro No. 1 Bandar Lampung 35145
}

\begin{abstract}
This study aims to analyze the performance of Indonesian exports to export destination countries in the international market. The subjects of this study are two Indonesian palm oil commodities: crude palm oil or CPO and processed palm oil or OPO (Other Palm Oil). There are four Indonesian palm oil markets in the international market, namely the Asian market, the European market, the African market, the American market, and the Australian market. The data used in this study is a time series from 1991 to 2016 and analyzed using the CMS (Constant Market Share) method. The CMS method explains the export growth performance in several components, which are the standard growth effect, the effect of product composition, the effect of market distribution, and the effect of competitiveness. The results showed that the performance of Indonesian CPO exports in the period 1991-2016 tended to decline compared to the growth of exports of all world products. Indonesian CPO is more competitive in the Asian market than the European market. The dynamics of Indonesian CPO exports in the African, American and Australian markets are quite good, but these three markets have not become the main destinations for Indonesian CPO exports. Indonesia's OPO export performance in the 1991-2016 period tended to increase compared to the growth in exports of all world products. Indonesian OPO in the Asian and African markets is more competitive than the European market. The dynamics of Indonesia's OPO exports on the American market and the Australian market are quite good, but these two markets have not become the main destinations for Indonesia's OPO market. Thus, Indonesia can maximize the performance of OPO exports when there is a rejection of Indonesian OPO in the international market.
\end{abstract}

Keywords: CPO, constant market share (CMS), export, palm oil, performance

\begin{abstract}
Abstrak: Penelitian ini bertujuan menganalisis kinerja ekspor Indonesia ke negara tujuan ekspor di pasar internasional. Komoditas minyak sawit Indonesia yang diteliti terdiri dari minyak sawit mentah atau CPO (Crude Palm Oil) dan minyak sawit olahan atau OPO (Other Palm Oil). Ada empat pasar minyak sawit Indonesia di pasar internasional, yaitu pasar Asia, pasar Eropa, pasar Afrika, pasar Amerika, dan pasar Australia. Data yang digunakan dalam penelitian ini adalah deret waktu dari 1991 hingga 2016. Metode analisis yang digunakan dalam penilitian ini adalah metode CMS (Constant Market Share). Metode CMS menjelaskan kinerja pertumbuhan ekspor dalam beberapa komponen yaitu efek pertumbuhan standar, efek komposisi produk, efek distribusi pasar, dan efek daya saing. Hasil penelitian menunjukkan bahwa kinerja ekspor CPO Indonesia pada periode 1991-2016 cenderung menurun dibandingkan dengan pertumbuhan ekspor semua produk dunia. CPO Indonesia lebih kompetitif di pasar Asia daripada pasar Eropa. Dinamika ekspor CPO Indonesia di pasar Afrika, Amerika dan Australia cukup baik, tetapi ketiga pasar ini belum menjadi tujuan utama ekspor CPO Indonesia. Kinerja ekspor OPO Indonesia pada periode 1991-2016 cenderung meningkat dibandingkan dengan pertumbuhan ekspor semua produk dunia. OPO Indonesia di pasar Asia dan Afrika lebih kompetitif daripada pasar Eropa. Dinamika ekspor OPO Indonesia di pasar Amerika dan pasar Australia cukup baik tetapi kedua pasar ini belum menjadi tujuan utama pasar OPO Indonesia. Dengan demikian, Indonesia dapat memaksimalkan kinerja ekspor OPO ketika ada penolakan OPO Indonesia di pasar internasional.
\end{abstract}

Kata kunci: CPO, constant market share (CMS), ekspor, minyak sawit, kinerja

${ }^{1}$ Corresponding author:

Email: hismono@yahoo.com 


\section{INTRODUCTION}

Indonesia's palm oil production is mostly exported to foreign countries. Indonesia's palm oil exports reach five continents, namely Asia, Europe, Africa, America, and Australia, with a major share in Asia. According to the BPS (2016), Indonesia's palm oil export volume in 2015 consisted of Crude Palm Oil (HS 151110), Other Palm Kernel Oil (HS 151329), Crude Oil of Palm Kernel (HS 151321), and Other Palm Oil (HS HS 151190).

Crude Palm Oil (CPO) is a palm oil product that has a fairly high level of consumption in the European Union (Oil World, 2014). The European Union is a prospective market for Indonesian CPO. In addition to developing CPO-derived products, such as edible oil and margarine, the European Union is the world's largest biodiesel producer and uses $\mathrm{CPO}$ as a raw material for processing these alternative fuels. The consumption of palm oil in the world is the highest compared to the consumption of rape oil, sunflower oil, and soybean oil in 2014. Palm oil consumption in 2000 of 23.6 million tons increased to 62 million tons in 2014, up 45 percent, while soybean oil consumption fell from 27.8 million tons (2011) to 4.7 million tons (2014) or fell 69 percent. This trend shows a shift in world vegetable oil consumption (Oil World, 2014). However, the increase in consumption of palm oil did not offset the increase in consumption of other vegetable oils, resulting in a shift in consumption from corn oil, soybean oil, sunflower oil, and rape oil into palm oil.

To overcome the decline in demand for conventional vegetable oils, which are mostly produced by western countries, European countries have implemented nontariff barriers in the form of black campaigns for palm oil. In addition to The World Health Organization (WHO) recommendation of reducing CPO consumption because it causes cardiovascular diseases, several environmental organizations in the west also published research on deforestation, orangutan habitat destruction, and the greenhouse effect caused by the development of oil palm plantations (Syaukat, 2010). The negative issues on palm oil, both in the form of health issues and environmental issues, is having a negative impact on the performance of Indonesian palm oil in the international market (Dradjat, 2012).
One of the impacts felt during the last five years is the decline in world palm oil prices. Based on GAPKI data (2017), throughout 2016 the average price of global crude palm oil fell by 14 percent compared to 2015 . Although the volume of Indonesia's palm oil exports has continued to increase from year to year, the value of Indonesia's palm oil exports is still volatile. The low price of global palm oil is inseparable from the impact of the fall in world crude oil prices which had fallen to US $\$ 30$ per barrel, which then affected other commodity prices. China's slowing economic growth and stagnation in Europe are also factors that caused a decline in world palm oil prices (GAPKI, 2017).

In the development of world vegetable oil exports, Indonesia as a producer of palm oil is in a weak position. Efforts are needed to improve Indonesia's bargaining position in determining the export prices of world palm oil. Fluctuations in world palm oil prices and changes in Indonesian export duty policies of palm oil have triggered a decline in Indonesia's palm oil exports in 2016. The decline in palm oil exports has caused domestic stocks to rise, resulting in the decline in domestic oil prices. The decline in domestic palm oil prices will certainly reduce the surplus of consumers and producers, namely farmers and downstream industries. The decrease in producers' surplus will be charged to farmers in the form of a decrease in the price of fresh fruit bunches (FFB) so that it will also have an impact on reducing incentives for farmers to improve the quality of FFB. This condition certainly has an impact on competitiveness and export earnings. Low export income causes the demand for various domestic sectors to decline, causing the level of domestic economic activity to decline and the number of unemployment to increase.

This research is based on a similar previous study conducted by Hagi (2012), Ermawati and Saptia (2013), and Prasetyo et al. (2017). Hagi's research (2012) analyzed the competitiveness of Indonesian and Malaysian palm oil exports in the international market 1995-2009. Based on CMS analysis, Indonesian palm oil is more competitive than Malaysia on the Asian Continent, while Malaysian palm oil is more competitive than Indonesia on the European Continent. Ermawati and Saptia's (2014) research on the performance of Indonesia's palm oil exports. The results of the CMS analysis show that Indonesia's CPO and PKO exports 
tend to decrease compared to exports of all products in the world. Besides that, there are still many negative parameters for the effects of product composition, market distribution, and competitiveness. Research by Prasetyo et al. (2017) analyzes the comparative advantage and performance of Indonesia's crude palm oil exports in the international market. Based on CMS analysis, Indonesia's CPO export performance is lower than Malaysia's CPO export performance in terms of growth, market distribution, and competitiveness; but better in the aspect of product composition. This study differs from the previous researches in that the subject of the study is not only $\mathrm{CPO}$ but also $\mathrm{CPO}$ preparations known as Other Palm Oil (OPO). In addition, this study also analyzes export performance not only in Asian and European markets but also export performance in African, American, and Australian markets to find new markets for Indonesian $\mathrm{CPO}$ and OPO products. The purpose of this study is to analyze the performance of Indonesian palm oil exports in the international market.

\section{METHODS}

This study used secondary data of the volume and value of Indonesia's palm oil exports to countries in five markets, namely the Asian market, the European market, the African market, the American market, and the Australian market in 1991-2016. Five markets were chosen to see the development of Indonesia's palm oil exports in each market. Harmonized System (HS) used in this study is HS 4 digit level, namely HS 1511 with commodity Palm oil (Palm Oil and its fraction) consisting of oil HS 151110 or crude palm oil and HS 151190 or oil refined palm (Other Palm Oil).

The type of data used in this study is secondary data in the form of time series data for 26 years, namely the period 1991 to 2016. Secondary data obtained from the Central Statistics Agency [BPS], Directorate General of Plantations, Ministry of Agriculture of the Republic of Indonesia (Ditjenbun Kementan RI), United Nations Commodity of Trade (UN Comtrade), Center for Agricultural Data and Information Systems, Ministry of Trade (Ministry of Trade), Ministry of Finance, previous research, research journals, books, and literature relating to competitiveness and trade international palm oil.
The method used in this research is descriptive and quantitative methods. Descriptive method is used to interpret data regarding export development and the performance of Indonesian palm oil. Data processing in this study uses Microsoft Excel 2010 software and Eviews.

To analyze the performance of Indonesia's palm oil exports on the international market, the Constant Market Share (CMS) method is used. The method of analysis is only used for oil palm products, especially $\mathrm{CPO}$ and OPO. According to Tambunan (2001), there are four terms in the CMS model, which are as follows.

\section{The Standard Growth}

The standard growth parameter shows the general standard of export growth of countries in the world. If the growth in export standards is higher, it indicates that Indonesia's export performance is better. Vice versa, if the growth of standard exports is lower than the growth of Indonesian exports to importing countries shows Indonesia's export performance is worse. Mathematically can be written with the following formula.

$$
\mathrm{g}=\frac{E(t)-E(t-1)}{E(t-1)}
$$

\section{Product Composition Effect}

The effect of product composition shows whether a country has concentrated on a rapidly developing commodity market. Positive parameters indicate that exporting countries (for example, Indonesia) export products to countries that have higher product import growth compared to the growth of these product groups. If the opposite occurs, the effect of the composition of the product is negative. The following formula describes the product composition effect.

$$
\frac{\sum_{i}\left(g_{i}-g\right) E_{(t-1)}}{E_{(t-1)}}
$$

Market Distribution Effects

Market distribution effects measure export performance by analyzing gains or losses in the country's exports of concern (for example Indonesia) as a result of changes in the relative size of the export market. The parameter is positive if the exporting country (for example Indonesia) is to distribute its market to the center 
of demand growth. Otherwise, the effect of market distribution will be negative. The following formula describes the market distribution effect.

$$
\frac{\sum_{i} \sum_{j}\left(g_{i j}-g_{i}\right) E_{(t-1) i j}}{E_{(t-1)}}
$$

\section{Competitiveness Effect}

Richardson (1971) suggested that the effect of competitiveness indicates export growth arising from changes in the export market share. If the competitiveness effect parameter is positive, it means that Indonesia is strong among other competitors. Conversely, if the parameter is a negative one, it means that Indonesia is weak (Hadi and Mardianto, 2004). The effect of competitiveness is described in the following formula.

$$
\frac{\sum_{i} \sum_{j}\left(E_{(t) i j}-E_{(t-1) i j}-g_{i j} E_{(t-1) i j}\right)}{E_{(t-1)}}
$$

Shows :

$$
\begin{aligned}
& \mathrm{g}=\frac{W(t)-W(t-1)}{W(t-1)} \\
& \mathrm{g}_{\mathrm{i}}=\frac{W(t) i-W(t-1) i}{W(t-1) i} \\
& \mathrm{~g}_{\mathrm{ij}}=\frac{W(t) i j-W(t-1) i j}{W(t-1) i j}
\end{aligned}
$$

Description: E (t) (Total exports of all Indonesian products in year $(\mathrm{t})$ ); $\mathrm{E}(\mathrm{t}-1)$ (Total exports of all Indonesian products in the year (t-1)); E ( $\mathrm{t}) \mathrm{i}$ (Total exports of Indonesian CPO/OPO products in year $(\mathrm{t})$ ); $E(t) j$ (Total exports of all products to country $j$ in year (t)); E (t) ij (Total exports of Indonesian CPO/OPO products to country $\mathrm{j}$ in year $(\mathrm{t})$ ); $\mathrm{W}(\mathrm{t})$ (Total exports of all world products in year $(\mathrm{t})$ ); $\mathrm{W}(\mathrm{t})$ I (Total world $\mathrm{CPO} / \mathrm{OPO}$ product exports in year $(\mathrm{t})$ ); $\mathrm{W}(\mathrm{t}) \mathrm{j}$ (Total exports of all world $\mathrm{j}$ products in year $(\mathrm{t})) ; \mathrm{W}(\mathrm{t}) \mathrm{ij}$ (Total world $\mathrm{CPO} / \mathrm{OPO}$ product exports to country $\mathrm{j}$ in year (t)); W (t-1) (Total exports of all world products in year (t-1)).

The framework of thought in this study can be seen in Figure 1. Indonesia's palm oil production from 1991 to 2016 continues to increase. Increased palm oil production drives an increase in the volume of Indonesia's palm oil exports to the international market. However, the increase in the volume of exports of
Indonesian palm oil is not accompanied by an increase in the value of exports. Therefore, this study examines the performance of Indonesia's palm oil exports in the international market.

\section{RESULTS}

\section{Development of Indonesia's Palm Oil Exports}

Indonesia's palm oil exports (HS 1511) consist of exports of crude palm oil or CPO with the code HS 151110 and exports of processed palm oil or OPO (Other Palm Oil) with the HS 151190 code. The development of the volume of crude palm oil exports (CPO) and Indonesian OPO from 1991 to 2016 can be seen in Figure 2.

Based on Figure 2, it is known that Indonesia's CPO export volume fluctuated with an upward trend in the period 1991 to 2011. Indonesia's CPO export volume increased from 1.08 million tons (1991) to 8.4 million tons (2011). Whereas in 2012 to 2016 there was a fluctuation with a downward trend. During the period 1991 to 2016, the average growth rate of Indonesia's CPO export volume was $14 \%$ per year.

Indonesia's export volume of processed palm oil (OPO) (Figure 2) fluctuated with an upward trend in the 1991-2016 period of 83,180 tons (1991), increasing to 17.4 million tons (2016). Meanwhile, the value of Indonesia's OPO exports has also fluctuated with an upward trend of 27 million dollars (1991), increasing to 11 billion dollars (2016). During the period 1991 to 2016, the average growth rate of Indonesia's OPO export volume was $33 \%$ per year. The increase in Indonesia's OPO export volume is inseparable from the growing processing industry of Indonesian palm oil products.

The decline in Indonesian $\mathrm{CPO}$ exports in the international market due to demand for $\mathrm{CPO}$ and world CPO prices declined so that Indonesian palm oil producers export more palm oil products in the form of refined palm oil (OPO). Indonesia's palm oil exports in the international market are divided into several territories, namely the Asian market, the European market, the African market, the American market, and the Australian market. In each market, it consists of countries that are in the same territory. 


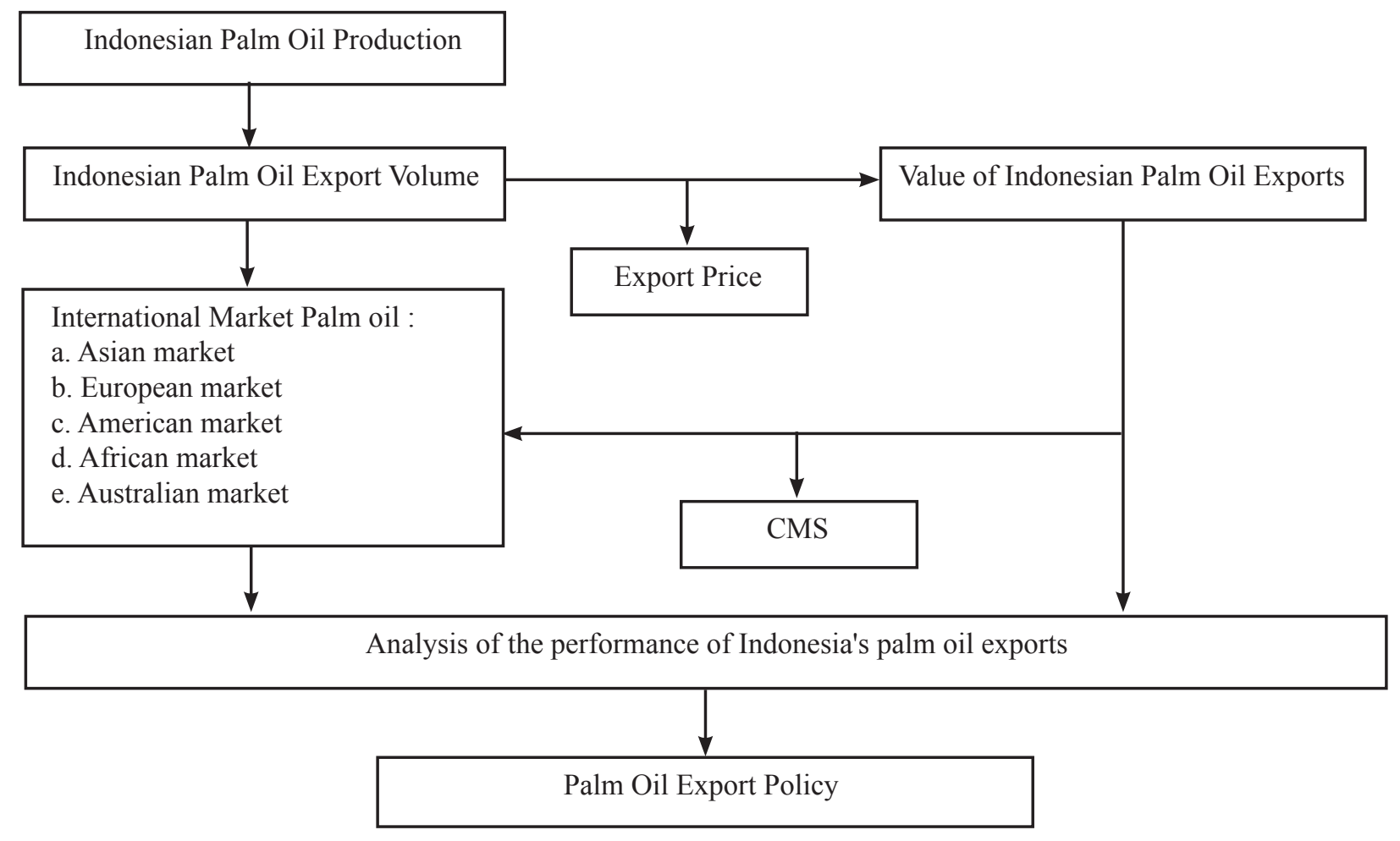

Figure 1. Research framework

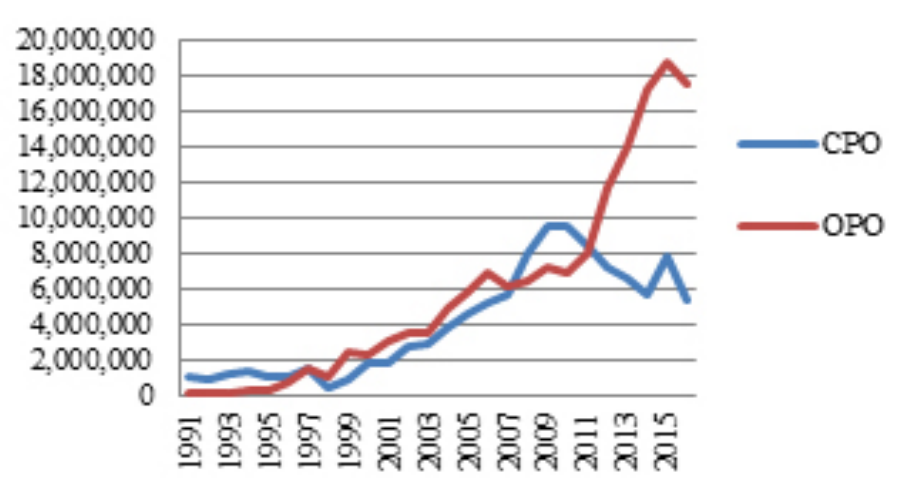

Figure 2. Development of Indonesia's CPO and OPO export values in 1991-2016 (Um Comtrade, 2017)

The development of Indonesia's CPO export volume from 2011 to 2016 (Table 1) revealed that there was a decline in the volume of Indonesian CPO exports on the international market during the period 2010 to 2016 in line with the decline in world CPO prices. Indonesia's $\mathrm{CPO}$ export volume in the Asian market ranked first, then continued in the European market in second place, the African market ranked third. The American market and the Australian market are ranked fourth and fifth export destination markets for Indonesian CPO.
The development of Indonesia's OPO export volume in the international market in the period 2011 to 2016 (Table 2) shows that Indonesia's OPO exports have fluctuated and tended to increase in each export destination market. The Asian market is the main market destination for Indonesia's OPO exports. It is then followed by the African market, the European market, the American market, and the Australian market.

\section{CMS Analysis of Indonesian CPO Commodities to the International Market}

Analysis of the Constant Market Share (CMS) of CPO commodities in 1991-2016 shows that the average growth of Indonesia's CPO exports is higher than the average growth of world CPO exports, as shown in Table 3. Analysis of the effects of 1991-2016 standard growth in Table 3 shows that the growth of Indonesia's CPO exports is higher than world CPO, except for 1994, 1995, 1996, 1998, 2001, 2003, 2006, 2011, 2012 and 2013, which is indicated by the negative deviation between the growth of Indonesian and world exports.

The growth of Indonesian CPO exports from 1994 to 1996 was lower than the growth of world CPO exports due to concerns about rising cooking oil prices, therefore the government issued an export levy policy or now better known as export duties. 
Table 1. Development of Indonesia's CPO export volume HS 151110 in 2010-2016

\begin{tabular}{cccccc}
\hline \multirow{2}{*}{ Year } & \multicolumn{5}{c}{ Indonesian CPO Export Volume (Ton) } \\
\cline { 2 - 6 } & Asia & Europe & Africa & America & Australia \\
\hline 2011 & 6.416 .444 & 1.724 .705 & 277.889 & 4.500 & 500 \\
2012 & 4.913 .918 & 2.104 .387 & 232.674 & 1.501 & 40 \\
2013 & 3.929 .334 & 2.450 .145 & 203.975 & NA & 1.278 \\
2014 & 3.697 .693 & 1.898 .528 & 127.099 & 2.500 & 1.000 \\
2015 & 5.104 .028 & 2.417 .837 & 264.685 & 2.000 & NA \\
2016 & 3.710 .485 & 1.390 .171 & 183.296 & NA & 1 \\
Total & 34.836 .630 & 14.379 .446 & 1.536 .120 & 23.502 & 5.819 \\
\hline
\end{tabular}

Source: UN Comtrade, 2017

Table 2. Development of Indonesia's OPO export volume HS 151190 in 2010-2016

\begin{tabular}{cccccc}
\hline \multirow{2}{*}{ Year } & \multicolumn{5}{c}{ Indonesian OPO Export Volume (Ton) } \\
\cline { 2 - 6 } & Asia & Europe & Africa & America & Australia \\
\hline 2011 & 4.537 .099 & 1.376 .364 & 1.851 .902 & 244.844 & 5.377 \\
2012 & 7.526 .840 & 1.427 .721 & 2.348 .492 & 276.145 & 13.303 \\
2013 & 8.060 .293 & 2.227 .265 & 2.964 .358 & 724.431 & 16.896 \\
2014 & 8.806 .736 & 3.018 .708 & 4.428 .816 & 816.290 & 95.017 \\
2015 & 11.007 .604 & 2.453 .014 & 4.253 .698 & 936.814 & 27.861 \\
2016 & 10.160 .380 & 2.908 .144 & 3.249 .291 & 1.067 .370 & 90.166 \\
Total & 54.318 .805 & 14.392 .981 & 20.515 .681 & 4.270 .411 & 271.048 \\
\hline
\end{tabular}

Source: UN Comtrade, 2017

Table 3. Analysis of the effect of Indonesia's CPO standard growth in 1991-2016

\begin{tabular}{|c|c|c|c|c|}
\hline \multirow{2}{*}{ Years } & \multicolumn{2}{|c|}{ CPO Export Growth } & \multirow{2}{*}{ StdDev } & \multirow{2}{*}{$\begin{array}{c}\text { Standard } \\
\text { Growth Effect }\end{array}$} \\
\hline & Indonesia & World & & \\
\hline 1991 & - & - & - & - \\
\hline 1992 & 0.08 & 0.03 & 0.05 & 0.03 \\
\hline 1993 & 0.24 & 0.24 & 0.00 & 0.21 \\
\hline 1994 & 0.40 & 0.43 & -0.03 & 0.37 \\
\hline 1995 & 0.02 & 0.15 & -0.13 & 0.11 \\
\hline 1996 & -0.18 & -0.08 & -0.09 & -0.06 \\
\hline 1997 & 0.44 & 0.10 & 0.34 & 0.09 \\
\hline 1998 & -0.68 & 0.02 & -0.70 & 0.00 \\
\hline 1999 & 0.22 & -0.25 & 0.47 & -0.11 \\
\hline 2000 & 0.76 & 0.45 & 0.31 & 0.25 \\
\hline 2001 & -0.15 & 0.11 & -0.26 & 0.05 \\
\hline 2002 & 1.19 & 0.60 & 0.60 & 0.35 \\
\hline 2003 & 0.19 & 0.27 & -0.08 & 0.15 \\
\hline 2004 & 0.36 & 0.26 & 0.10 & 0.15 \\
\hline
\end{tabular}

The existence of a ban on Indonesian CPO exports in 1998 was due to the scarcity of domestic CPO which caused an increase in the price of cooking oil (Rifin and Feriyanto, 2017). European Union policies through the Renewable Energy Directive (RED) impose antidumping tariffs on Indonesia's CPO exports to Europe up to 178.85 euros per ton. This rate resulted in a drastic reduction in Indonesia's CPO exports to the European

\begin{tabular}{|c|c|c|c|c|}
\hline \multirow{2}{*}{ Years } & \multicolumn{2}{|c|}{ CPO Export Growth } & \multirow{2}{*}{ StdDev } & \multirow{2}{*}{$\begin{array}{c}\text { Standard } \\
\text { Growth Effect }\end{array}$} \\
\hline & Indonesia & World & & \\
\hline 2005 & 0.10 & 0.03 & 0.07 & 0.02 \\
\hline 2006 & 0.25 & 0.32 & -0.07 & 0.20 \\
\hline 2007 & 0.88 & 0.74 & 0.13 & 0.48 \\
\hline 2008 & 0.75 & 0.67 & 0.09 & 0.45 \\
\hline 2009 & -0.13 & -0.16 & 0.03 & -0.11 \\
\hline 2010 & 0.34 & 0.32 & 0.02 & 0.23 \\
\hline 2011 & 0.15 & 0.38 & -0.23 & 0.23 \\
\hline 2012 & -0.24 & -0.11 & -0.13 & -0.05 \\
\hline 2013 & -0.25 & -0.28 & 0.03 & -0.15 \\
\hline 2014 & -0.16 & -0.02 & -0.13 & -0.01 \\
\hline 2015 & 0.04 & -0.07 & 0.12 & -0.04 \\
\hline 2016 & -0.25 & -0.26 & 0.02 & -0.14 \\
\hline Average & 0.18 & 0.15 & 0.02 & 0.11 \\
\hline
\end{tabular}

Source: UN Comtrade, 2017

Union from 1.2 million tons (2012) to 387 thousand (2013) down 66 percent (Wisadhana and Bagus, 2015; Widyaningtyas, 2016). Indonesia's CPO export growth in 1991-2016 utilized more economic opportunities to increase CPO trade growth in the international market except in 1996, 1999, 2009, 2012, 2013, 2014, 2014, and 2015, which was shown by the effect of negative standard growth. 
Based on the results of CMS calculations, it is known that the commodity effect of Indonesian CPO products on the international market in the 1991-2016 period was positive (0.040752). The contribution of the composition of Indonesian CPO products in the international market in that period was quite good. It indicates that Indonesia has taken the opportunity to export $\mathrm{CPO}$ products by taking into account the growth of $\mathrm{CPO}$ exports in importing countries according to product composition.

The results of the CMS calculation show that the effect of the distribution of the Indonesian CPO market to countries in the Asian, European, and African markets (Table 4) in the 1991-2016 period was negative. It shows that Indonesia's CPO export growth to countries in the Asian, European and African markets is still lower than the growth of CPO imports in these countries. Meanwhile, a lot of the parameters of the effect of the distribution of the Indonesian CPO market to countries in the American and Australian markets are positive. It shows that the growth of Indonesia's CPO exports to countries in the American and Australian markets is higher than the growth of CPO imports in these countries. However, the American market and the Australian market have not yet become the main markets for Indonesia's CPO exports because the countries in the American market are also CPO producing countries. $\mathrm{CPO}$ producing countries in the American market are Colombia, Ecuador, Honduras, and Brazil (GAPKI, 2017).

The results of the calculation of the effect of Indonesia's CPO competitiveness on the international market in Table 4 show that Indonesia's CPO in the Asian, American, and Australian markets is more competitive than European and African markets. It means that Indonesia has weak competitiveness and has not been able to compete with other $\mathrm{CPO}$ exporting countries in the European and African markets. Indonesian CPO has not been able to compete in the European market due to negative issues regarding Indonesian CPO (Pratiwi, 2013; Azizah, 2015; Turnip et al. 2016). The difference in weighting the export duty for Rotterdam and Malaysian exchanges by $20 \%$ and the Indonesian exchange by $60 \%$ also caused a decline in Indonesia's CPO export performance (Rifin and Feryanto, 2017). Indonesian $\mathrm{CPO}$ has not been able to compete with other exporting countries in the African market. Countries in the African market are also CPO producing countries such as Nigeria, Kenya, Benin and South Africa (UN Comtrade, 2017).
Table 4. Results of the calculation of the effects of market distribution and the effect of the competitiveness of Indonesian CPO on the international market in 1991-2016

\begin{tabular}{|c|c|c|c|}
\hline Market & Country & $\begin{array}{c}\text { Market } \\
\text { Distribution } \\
\text { Effect }\end{array}$ & $\begin{array}{c}\text { Competi- } \\
\text { tiveness } \\
\text { Effect }\end{array}$ \\
\hline \multirow[t]{9}{*}{ ASIA } & India & 0.009471 & -0.003744 \\
\hline & Singapore & -0.000871 & -0.000493 \\
\hline & Korea & -0.000019 & 0.000041 \\
\hline & Vietnamese & -0.000865 & 0.000053 \\
\hline & Malaysia & -0.003379 & 0.000675 \\
\hline & China & -0.004139 & -0.000066 \\
\hline & Bangladesh & -0.000888 & -0.000033 \\
\hline & $\begin{array}{l}\text { Uni Emirat } \\
\text { Arab }\end{array}$ & -0.000009 & 0.000013 \\
\hline & Pakistan & -0.001793 & -0.000705 \\
\hline \multirow[t]{8}{*}{ EUROPE } & Denmark & -0.000205 & 0.000049 \\
\hline & Netherlands & -0.009616 & -0.001943 \\
\hline & German & -0.001649 & -0.000378 \\
\hline & Greece & -0.000085 & -0.000081 \\
\hline & Italy & 0.001707 & -0.001806 \\
\hline & Spanish & 0.000668 & -0.000972 \\
\hline & Portugal & -0.000038 & 0.002863 \\
\hline & England & -0.002337 & -0.001373 \\
\hline \multirow[t]{9}{*}{ AFRICA } & Tanzania & 0.000844 & 0.000169 \\
\hline & Ghana & -0.000124 & -0.000024 \\
\hline & Moroco & 0.000125 & -0.000014 \\
\hline & Kenya & -0.000986 & -0.002316 \\
\hline & D'Ivoire & -0.000344 & 0.000377 \\
\hline & Ukraine & -0.000590 & -0.000054 \\
\hline & Cameroon & 0.000138 & -0.000263 \\
\hline & Mozambique & 437.408544 & 0.000089 \\
\hline & Egypt & -0.000216 & -0.001562 \\
\hline \multirow[t]{7}{*}{ AMERICA } & USA & -0.000157 & 0.000041 \\
\hline & Mexico & -0.000541 & -0.000531 \\
\hline & Panama & -0.000022 & 0.000001 \\
\hline & Brazil & 0.000019 & 0.000099 \\
\hline & Costarica & -0.000040 & 0.000002 \\
\hline & Dominica & 0.000001 & 0.000000 \\
\hline & Colombia & 0.000000 & -0.000017 \\
\hline \multirow[t]{6}{*}{ AUSTRALIA } & Australia & -0.000443 & 0.000001 \\
\hline & Papua Nugini & -0.000006 & 0.000000 \\
\hline & Samoa & 0.000000 & 0.000000 \\
\hline & Micronesia & 0.000000 & 0.000000 \\
\hline & Mauritius & -0.000003 & -0.000008 \\
\hline & Marshal & 0.000000 & 0.000000 \\
\hline
\end{tabular}

Source: UN Comtrade, 2017 (Processed) 
In general, Indonesia's CPO export performance in the international market has decreased. This is in line with research by Radifan (2014) and Maygirtasari (2015). The decline in Indonesia's CPO export performance in the Asian market is due to India and China imposing high import duties to protect domestic vegetable products (Rifin, 2013). The anti-dumping policy of the European Union countries towards Indonesian CPO has caused a decrease in $\mathrm{CPO}$ exports in the European market. Countries in Europe set additional import duties for Indonesian $\mathrm{CPO}$ because $\mathrm{CPO}$ is considered as damaging as alcohol. The United States has also begun to consider implementing an anti-dumping policy on Indonesian palm oil products (Rostia, 2016).

\section{CMS Analysis of Indonesia's Other Palm Oil (OPO) Commodities to the International Market}

In addition to the CPO commodity (crude palm oil), CMS analysis was also carried out on the processed palm oil commodity (OPO) to determine its export performance. OPO commodities are processed products from crude palm oil or CPO. The OPO commodity with HS 151190 is a combination of several CPO processed products such as fatty acids, cooking oil, butter, and others.

The results of the analysis of the effects of Indonesia's OPO standard growth in 1991-2016 show that Indonesia's OPO export growth is higher than the world OPO, except in 1992, 1995, 1998, 2003, 2007, 2008, and 2010, which is shown by the negative deviation between Indonesia's export growth and world. Indonesia's OPO export growth in 1991-2016 used more economic opportunities to increase OPO trade growth in the international market except in 1999, 2000, 2001, 2005, 2009, 2012, 2013, 2015 and 2016, which is shown by the negative growth effect of the standard which is negative as shown in Table 5.

The low growth of OPO exports in 1995 was due to an export levy policy for CPO products and their preparations. So that a decline in exports of processed palm oil. The Indonesian government banned palm oil exports in 1998 because domestic cooking oil prices increased. In 2007 and 2008, the government raised export levies coupled with progressive taxes to prevent domestic cooking oil shortages so that in recent years Indonesia's OPO export growth was low.
Table 5. Analysis of the effects of Indonesia's OPO standard growth in 1991-2016

\begin{tabular}{|c|c|c|c|c|}
\hline \multirow{2}{*}{ Years } & \multicolumn{2}{|c|}{ CPO Export Growth } & \multirow{2}{*}{ StdDev } & \multirow{2}{*}{$\begin{array}{c}\text { Standard } \\
\text { Growth Effect }\end{array}$} \\
\hline & Indonesia & World & & \\
\hline 1991 & - & - & - & - \\
\hline 1992 & -0.12 & 0.22 & -0.34 & 0.00 \\
\hline 1993 & 1.49 & 0.10 & 1.39 & 0.00 \\
\hline 1994 & 1.35 & 0.54 & 0.81 & 0.02 \\
\hline 1995 & 0.13 & 0.26 & -0.13 & 0.01 \\
\hline 1996 & 1.16 & 0.00 & 1.16 & 0.00 \\
\hline 1997 & 1.21 & 0.10 & 1.10 & 0.02 \\
\hline 1998 & -0.30 & 0.10 & -0.40 & 0.01 \\
\hline 1999 & 0.61 & -0.10 & 0.71 & -0.02 \\
\hline 2000 & -0.28 & -0.30 & 0.02 & -0.05 \\
\hline 2001 & 0.10 & -0.05 & 0.15 & -0.01 \\
\hline 2002 & 0.78 & 0.50 & 0.28 & 0.12 \\
\hline 2003 & 0.16 & 0.32 & -0.16 & 0.07 \\
\hline 2004 & 0.43 & 0.14 & 0.29 & 0.04 \\
\hline 2005 & 0.08 & -0.05 & 0.13 & -0.02 \\
\hline 2006 & 0.31 & 0.21 & 0.09 & 0.07 \\
\hline 2007 & 0.46 & 0.58 & -0.11 & 0.18 \\
\hline 2008 & 0.41 & 0.50 & -0.10 & 0.15 \\
\hline 2009 & -0.20 & -0.27 & 0.07 & -0.08 \\
\hline 2010 & 0.25 & 0.27 & -0.02 & 0.08 \\
\hline 2011 & 0.46 & 0.38 & 0.08 & 0.13 \\
\hline 2012 & 0.29 & -0.02 & 0.30 & -0.01 \\
\hline 2013 & -0.01 & -0.07 & 0.07 & -0.03 \\
\hline 2014 & 0.22 & 0.07 & 0.15 & 0.04 \\
\hline 2015 & -0.17 & -0.20 & 0.03 & -0.11 \\
\hline 2016 & 0.01 & -0.04 & 0.05 & -0.02 \\
\hline Average & 0.35 & 0.13 & 0.22 & 0.02 \\
\hline
\end{tabular}

Source: UN Comtrade, 2017 (Processed)

Based on the results of CMS calculations, it is known that the commodity effects of Indonesian OPO products on the international market in the 1991-2016 period were positive (0.041986). The contribution of the effects of the composition of Indonesian OPO products on the international market in the 1991-2016 period was quite good, thus indicating that Indonesia was able to take the opportunity to export OPO products by taking into account the growth of OPO exports in the importing country according to the product composition.

The results of the calculation of market distribution effects in Table 6 shows that the effects of Indonesia's OPO market distribution to countries in Asian and European markets in the 1991-2016 period are mostly negative. It shows that the growth of Indonesia's OPO exports to countries in Asian and European markets 
is still lower than the growth of OPO imports in these countries. Indonesian refined palm oil (OPO) does not yet have a good market position in Asian and European markets. Exports on OPO in Asian and European markets are still dominated by Malaysia. This is because the downstream industries in Malaysia are more developed than Indonesia. Malaysian OPO products are more trusted by countries in the Asian and European markets with the ongoing certification of RSPO palm oil.

However, in 2013-2016 Indonesia's OPO commodity export share $(53 \%)$ was able to dominate the market share above Malaysia (35\%) (UN Comtrade, 2017). This is due to the increasing downstream palm oil processing industry (processing) of Indonesia's OPO export performance also increased (Zainuddin, 2015; Rifin, 2017; Purba et al. 2018; Aulia et al. 2019).

The parameters of the effect of the Indonesian OPO market distribution to countries in the African, American, and Australian markets are positive. This shows that the growth of Indonesia's OPO exports to countries in the African, American and Australian markets is higher than the growth of OPO imports in these countries. Processed palm oil (OPO) Indonesia has a good market position in the African, American and Australian markets. Indonesia's good OPO market distribution position in the African, American and Australian markets suggests that Indonesia and Malaysia are very concerned about high import growth in the African, American and Australian markets.

However, the American market and the Australian market are not yet the main markets for Indonesia's $\mathrm{CPO}$ exports because countries in the American and Australian markets import OPO commodities from many EU countries, especially the Netherlands. The Netherlands imported CPO from Indonesia, then processed it into OPO refined palm oil (HS 111590) and then exported to European, American, and Australian markets (UN Comtrade, 2017).

The results of the calculation of the effects of Indonesia's OPO competitiveness on international markets in Table 6 show that Indonesia's OPO in the Asian, European, American, and Australian markets is more competitive than the African market. It means that Indonesia has weak competitiveness and has not been able to compete with other OPO exporting countries in the African market (Nigeria, Tanzania, and South Africa).
However, Indonesia's OPO exports to the African market have increased from year to year due to the addition of export destinations in the African market (UN Comtrade, 2017).

Indonesia's OPO export performance in the Asian and European markets has increased where Indonesian OPO products are very competitive. Although European countries reject Indonesian $\mathrm{CPO}$, Indonesian $\mathrm{OPO}$ products are still able to compete. Indonesia's OPO export performance in the American and Australian markets has also increased, but the American and Australian markets have not yet become the main destination for Indonesia's OPO exports. This is in line with research by Rifai (2014), where exports of processed palm oil or Indonesian OPO to the US market continue to increase along with the development of the palm oil derivative product industry.

\section{Managerial Implication}

According to the results of the study, Indonesia's $\mathrm{CPO}$ export performance has decreased. The decline in Indonesia's CPO export performance in the main $\mathrm{CPO}$ export markets, namely the Asian and European markets will have an impact on the industry and oil palm plantations. The palm oil production that continues to increase can not be absorbed by the market which will ultimately reduce the profits of the processing industry and oil palm plantations. This decline in profits will certainly also have an impact on the main producers of palm oil, namely smallholders. Farmers will get low FFB prices due to the abundant supply of palm oil.

Therefore, the downstream industry is one of the saviors of palm oil exports, where the added value of CPO can be increased by producing $\mathrm{CPO}$ processed products such as cooking oil, butter, and others. Referring to the results of the study, Indonesian $\mathrm{CPO}$ processed products, abbreviated as OPO, experienced an increase in export performance. The increase in Indonesia's OPO export performance in each market, namely the Asian, African, European, American and Australian markets, shows that Indonesia's OPO is quite attractive in the international market. The increase in Indonesia's OPO export performance has a positive impact where Indonesia has a large contribution to the national economy through increased value-added, export value performance, employment, equitable distribution of people's welfare, and contributions to state revenue (Kemenperin, 2017). The results of this study imply 
OPO Indonesia has the opportunity to strengthen its position in the world vegetable oil market, shifting Malaysia's position in the international market, by increasing the number and quality of processed palm oil products.

\section{CONCLUSIONS AND RECOMMENDATIONS}

\section{Conclusions}

Indonesia's CPO export performance in the 1991-2016 period tended to decline compared to the growth in exports of all world products. Indonesian CPO is more competitive in the Asian market than in the European market. The dynamics of Indonesia's CPO exports in the African, American and Australian markets are quite good, but these three markets are not yet the main destination for Indonesia's CPO exports.

Indonesia's OPO export performance in the 19912016 period tended to increase compared to the export growth of all world products. Indonesia's OPO in Asian and African markets is more competitive than European markets. The dynamics of Indonesia's OPO exports in the American market and the Australian market are quite good, but these two markets are not yet the main destination of the Indonesian OPO market.

The export performance of OPO (refined palm oil) products is better than CPO (crude palm oil) performance. Indonesia can maximize the performance of OPO exports when there is a rejection of Indonesia's $\mathrm{OPO}$ in the international market. Indonesia's OPO export performance has increased along with the development of the downstream industry of the Indonesian palm oil industry.

\section{Recommendations}

From this research, it is advisable that the government is expected to be more focused on developing the downstream industry so that exports of CPO processed products can be increased while taking into account the benefits at the farm level. The government is expected to develop new palm oil markets, especially in the African and American markets by diversifying products according to their individual needs. The government is expected to increase CPO storage infrastructure in the main export destination countries.

\section{REFERENCES}

Aulia RU, Harianto, Novianti T. 2019. Analisis posisi pasar Indonesia pada pasar Refined Palm Oil (RPO) di Negara Importir. Jurnal Penelitian Kelapa Sawit 27(1): 1-12. https://doi. org/10.22302/iopri.jur.jpks.v27i1.56.

Azizah. 2015. Analisis ekspor Crude Palm Oil (CPO) Indonesia di Uni Eropa Tahun 2000-2011. Economics Development Analysis Journal 4(3): 33-2.

[BPS] Badan Pusat Statistik. 2016. Statistik Kelapa Sawit Indonesia 2015. Badan Pusat Statistik. Jakarta.

Dradjat B. 2012. Upaya mengatasi Black Campaign Kelapa Sawit Dan Langkah Strategis Ke Depan. Bogor: Lembaga Riset Perkebunan Nusantara.

Hadi P, Mardianto S. 2004. Analisis komparasi daya saing produk ekspor pertanian antar negara ASEAN dalam era perdagangan bebas AFTA. Jurnal Agro Ekonomi 22(1): 46-73. https://doi. org/10.21082/jae.v22n1.2004.46-73.

GAPKI. 2017. Refleksi industri kelapa sawit 2016 dan prospek 2017. http://gapki.td/refleksi-industrikelapa-sawit-2016-prospek-2017/\#more1848 [21 Feb 2018].

Kemenperin. 2017. Kemenperin komit tumbuhkan industri olahan sawit. www.kemenperin.go.id/ artikel/16949/Kemenperin-Komit-TumbuhkanIndustri-Olahan-Sawit [5 Augt 2018].

MaygirtasariT. 2015. Faktor-faktoryang mempengaruhi volume Ekspor Crude Palm Oil (CPO) Indonesia. Jurnal Administrasi Bisnis (JAB) 25(2):1-8.

Oil World. 2014. Oil World Database. ISTA Mielke $\mathrm{GmbH}$, Jerman.

Prasetyo A, Marwanti S, Darsono. 2017. Comparative advantage and export performance of Indonesian crude palm oil in international markets. Jurnal Agro Ekonomi 35(2):89-103. https://doi. org/10.21082/jae.v35n2.2017.89-103.

Pratiwi PD. 2013. Dampak kebijakan pajak ekspor terhadap kinerja ekspor $\mathrm{CPO}$, produksi, dan konsumsi minyak goreng di pasar domestik. Jurnal AGRISE XIII(2):117-129.

Purba HJ, Sinaga BM, Novianti T, Kustiari R. 2018. Dampak kebijakan perdagangan terhadap pengembangan industri biodiesel Indonesia. Jurnal Agro Ekonomi 36(1): 1-24.

Radifan F. 2014. Faktor-faktor yang mempengaruhi ekspor crude palm oil Indonesia dalam perdagangan internasional. Economics 
Development Analysis Journal 3(2): 259-267.

Rifai N. 2014. Dampak pengembangan produk turunan minyak sawit terhadap peningkatan ekspor produk minyak sawit ke Pasar Amerika Serikat. Jurnal Agro Ekonomi 32 (2):107-125. https:// doi.org/10.21082/jae.v32n2.2014.107-125.

Rifin A. 2013. Analysis of Indonesia's market position in palm oil Market in China and India. Journal of Food Products Marketing 19(4): 299-310. https://doi.org/10.1080/10454446.2013.726950.

Rifin A. 2017. Efisiensi perusahaan crude palm oil (CPO) di Indonesia. Jurnal Manajemen \& Agribisnis 14(2):103-108. https://doi. org/10.17358/jma.14.2.103.

Rifin A, Feriyanto. 2017. Kebijakan bea keluar minyak kelapa sawit Indonesia: siapa yang untung. Warta Pengkajian Perdagangan Volume II(14): 25-29.

Richardson JD. 1971. Some sensitivity tests for a constant market share, analysis of export growth. Review of Economics and Statistics 53: 300-204. https://doi.org/10.2307/1937978.

Rostia YA. 2016. Langkah Indonesia menghadapi tuduhan Uni Eropa terhadap praktek dumping produk biodiesel Indonesia tahun 2013. JOM FISIP 3(2):1-18.
Syaukat Y. 2010. Menciptakan daya saing ekonomi dan lingkungan industri kelapa sawit Indonesia. Jurnal Agrimedia 15(1): 16-19.

Tambunan T. 2001. Perdagangan Internasional dan Neraca Pembayaran. Cetakan I. Jakarta: LPFEUI.

Turnip SML, Suharyono, Mawardi MK. 2016. Analisis daya saing Crude Palm Oil (CPO) Indonesia di pasar internasional. Jurnal Administrasi Bisnis (JAB) 39(1):185-285.

UN Comtrade. 2017. http://comtrade.un.org/data/ [27 May 2017].

Wisadhana AM, Bagus I. 2015. Analysis Of Green Protectionism Against The Barriers Of Indonesia's Crude Palm Oil (CPO) Export In The European Union. Bali: Udayana.

Widyaningtyas D, Widodo T. 2016. Analisis pangsa pasar dan daya saing CPO Indonesia di Uni Eropa. Jurnal Ekonomi Manajemen Sumber Daya 18(2): 138-145. https://doi.org/10.23917/ dayasaing.v18i2.4510.

Zainuddin. 2015. Dampak faktor internal dan eksternal terhadap industri kelapa sawit Indonesia: analisis model ekonometrika. Jurnal Ilmiah Universitas Batanghari Jambi 15(4):134-141. 